\title{
Effect of three composts with active ingredients of Pseudomonas fluorescens on the development of white root disease and production of rubber plants
}

\author{
NURHAYATI DAMIRI ${ }^{1, \vartheta}$, RIZAL ROFIQI ${ }^{1}$, MULAWARMAN ${ }^{1}$, SUPLI E. RAHIM ${ }^{2}$, TRI RAPANI FEBYANTI ${ }^{3}$ \\ ${ }^{1}$ Department of Plant pests and diseases, Faculty of Agriculture, Universitas Sriwijaya. Jl. Raya Palembang-Prabumulih Km 32, Indralaya, Ogan Ilir \\ 30662, South Sumatra, Indonesia. Tel.: +62-711-580663, Fax.: +62-711-580276. •email: nurhayati@ @p.unsri.ac.id. \\ ${ }^{2}$ Postgraduate Program, Universitas Kader Bangsa. Jl. Mayjen H.M. Ryacudu No. 88, 7 Ulu, Seberang Ulu I, Palembang 30253, South Sumatra, \\ Indonesia \\ ${ }^{3}$ Indonesian Rubber Research Institute Sembawa. Jl. Raya Palembang-Pangkalan Balai Km. 29, Sembawa, Banyuasin 30953, South Sumatra, Indonesia
}

Manuscript received: 4 June 2021. Revision accepted: 15 July 2021.

\begin{abstract}
Damiri N, Rofiqi R, Mulawarnam, Rahim SE, Febyanti TP. 2021. Effect of three composts with active ingredients of Pseudomonas fluorescens on the development of white root disease and production of rubber plants. Biodiversitas 22: $3237-3242$. White root disease (WRD) caused by Rigidoporus lignosus is a very dangerous disease and a scourge for rubber farmers because it can result in decreased production and kill rubber plants. This research was conducted to observe the impact of compost enriched with the biological agent Pseudomonas fluorescens on the development of white root disease and production in rubber plants. The results showed that the application of compost with active ingredient of $P$. fluorescens isolates A and B reduced the severity of white root disease in plants with mild, moderate and severe infections, $34.12 \%, 29.31 \%$ and $57.21 \%$ respectively. Application of compost with $P$. fluorescens isolates $\mathrm{A}$ and $\mathrm{B}$, either singly or in combination, can increase latex production. The treatment of giving compost enriched with $P$. fluorescens isolates AR and ABR on rubber plants infected with mild WRD resulted in the highest latex production of 406 gm and 402.74 gm per plant, respectively. These two treatments did not differ from each other but were significantly different from the other treatments and controls.
\end{abstract}

Keywords: White root disease, Pseudomonas fluorescens, compost, rubber production.

\section{INTRODUCTION}

White root disease (WRD) is caused by the fungus Rigidoporus lignosus (Klotszch) Imazeki. can cause damage to rubber plant roots because fungi can colonize in the roots and form rhizomorphic layers (Fairuzah et al. 2014). White root disease spreads rapidly and infects nearby trees, especially in areas with poor sanitation and drainage. The pathogens can also survive in the form of fruiting bodies on dead trees, branches, twigs, stumps and rotten leaves (Tangonan et al. 2008). According to (Amaria and Wardiana 2014; Manurung et al. 2015). R. lignosus is a soil fungus that can survive in the soil for years. The results of a survey conducted by the International Rubber Research and Development Board show that white root disease is an endemic disease that is very detrimental to several rubber-producing countries such as Indonesia, Malaysia and Thailand. This disease can cause major damage because it can cause the death of rubber plants and the cost of controlling it is quite high (Ogbebor et al. 2013; Dalimunthe et al. 2017). Symptoms of attack on rubber leaves which are Secondary symptoms on rubber plants are yellowing leaves with the edges or edges of the leaves folded in. At the severity, the leaves drop and the tip of the branch dies. Sometimes young leaves, flowers and fruit form early. Transmission of white root fungi can occur through the intersection of healthy rubber roots with the remnants of old plant roots, stumps, sick trees or due to wind gusts that carry mold spores which then fall on the roots of plants, grow and form colonies and then propagate to stump branch roots and move to nearby plant roots by linking the roots.

Generally, disease control is carried out using an integrated method of cultivation and fungicide use, however, it is known that fungicide use can have a negative impact on human health and the environment and leave residues on agricultural areas. The impact of continuous use of fungicides can also lead to resistance to pathogenic fungi (Yang et al. 2011; Nam et al. 2017). The use of biological agents as pathogenic controllers in plants has become a worldwide concern. The ability of biological agents to suppress the development of diseases in plants is also because the use of biological agents does not cause negative impacts on the environment. Disease control using biological agents such as bacteria or fungi has the potential to prevent and suppress the development of soil-borne pathogens. Besides that, biological agents also increase disease resistance. Numerous microbes have been reported to be used as biological control against plants pathogens. Generally, the biological agents in the rhizosphere are more adaptable and well developed so that they have a great opportunity to be developed as biopesticides (Malmierca et al. 2012). The antifungal activity of $P$. fluorescens varies widely, largely depending on the secretory ability of 
secondary metabolites, particularly lytic enzymes and antibiotics. Production of lytic enzymes such as chitinase, gluconase, pectinase; salicylic acid; iron $(\mathrm{Fe})$ - chelating siderophores; indole-3-acetic acid (IAA), secondary metabolic compounds and antibiotics are most likely mechanisms that play an important role in the antifungal activity of Pseudomonas. Several types of rhizobacteria are used as biological agents to control pathogens such as Pseudomonas fluorescens, Bacillus sp. (Manjunatha et al. 2012; Toua et al. 2013).

Pseudomonas sp. is one of the biological agents that have the potential to be developed as a biopesticide. Pseudomonas fluorescens and Bacillus sp. are effective in controlling white root disease in disease-endemic areas. $P$. fluorescens can increase phenolic compounds such as tannins, saponins, and glucosides in colonized plant tissues, suppress the amount of fusarium density of pathogens withered in tomatoes, suppress infection rates and reduce the intensity of attacks. The application of this agent can also increase plant height, root dry weight and tomato weight (Nasrun and Nurmansyah 2015; Soesanto et al. 2010), it was reported that $P$. fluorescens is able to inhibit the growth of Peronospora parasitica downy mildew in caisin. P. fluorescens can protect aloe plants against fusarium disease and also increase plant growth (Damiri et al. 2017)). P. fluorescens is one of the microbes that has been widely used as biological agents and is also known as Plant Growth Promoting Rhizobacteria (PGPR). $P$. fluorescens can produce antibiotics, siderophore and is able to colonize plant roots and induce resistance (Wahyuni et al. 2015)

P. fluorescens can control several plant pathogens such as Botrytis cinerea, Rhizoctonia solanacearum and Xanthomonas axonopodis (Haggag and Abo El Soud 2012; Manjunatha et al. 2012; Nawangsih et al. 2012). Several types of Pseudomonas sp. are capable of producing salicylic acid compounds, phenoloxidase and phenylalanine ammonia-lyase (PAL) compounds which can induce plant resistance to plant disease causes (Fallahzeda et al. 2009). The aim of the present investigation is to study the effect of three compost enriched with Pseudomonas sp. on the development of white root fungus (Rigidoporus lignosus) and rubber production in the field. The novelty of this research is compost enriched with biological agents which can suppress the development of white root disease and increase plant production.

\section{MATERIALS AND METHODS}

\section{Study area}

This research was conducted in Experimental Garden of Faculty of Agriculture, University of Sriwijaya at Gelumbang Village, Muara Enim District, South Sumatra, Indonesia with geographical coordinates $104^{\circ} 00^{\prime \prime} \mathrm{E}$, $3^{\circ} 0$ '0's.

In this study, 2 antagonistic bacterial isolates of Pseudomonas namely, $P$. fluorescens isolate A and $P$. fluorescens isolate B were taken from the Phytopathology Laboratory of the Faculty of Agriculture, which showed the best antagonism effects in suppressing the growth of $R$. lignosus. The study was conducted in a randomized block design (RBD) consisting of 9 treatments and 4 replications. The treatments were application of compost with the active ingredient of $P$. fluorescens isolate A on mild WRD infected rubber plant (AR): application of compost with the active ingredient of $P$. fluorescens isolate A on moderate WRD infected rubber plant (AS); application of compost with the active ingredient of $P$. fluorescens isolate $\mathrm{A}$ on severe WRD infected rubber plant (AP); application of compost with the active ingredient of $P$. fluorescens isolate $\mathrm{B}$ on mild WRD infected rubber plant (BR): application of compost with the active ingredient of $P$. fluorescens isolate $B$ on moderate WRD infected rubber plant (BS): application of compost with the active ingredient of $P$. fluorescens isolate B on severe WRD infected rubber plant (BP): application of compost with the active ingredient of P. fluorescens isolate A and B on mild WRD infected rubber plant (ABR), application of compost with the active ingredient of $P$. fluorescens isolate $\mathrm{A}$ and $\mathrm{B}$ on moderate WRD infected rubber plant (ABS), application of compost with the active ingredient of $P$. fluorescens isolate A and B on severe WRD infected rubber plant (ABP) and control (healthy rubber plants). Sterilized compost was added with pure bacterial culture and then incubated for 2 weeks. The dosage used for efficacy included $150 \mathrm{~g} /$ plant.

\section{Survey of rubber plants in the land infected with $\boldsymbol{R}$. lignosus}

Infected plants showing typical symptoms of WRD were collected directly on the basis of infection, i.e. mild, moderate and severe, from the rubber plantation in Gelumbang Village. The application of compost with the active ingredient of $P$. fluorescens was done by sprinkling the compost in the lines around the rubber plant.

\section{Making compost with the active ingredient $P$. flourescens}

Organic compost was first sterilized in an autoclave for 15 minutes at a temperature of $121{ }^{\circ} \mathrm{C}$, and then cooled. Furthermore, the suspension of Pseudomonas fluorescens was sprayed evenly on the previously sterilized compost. Application in the field was done by sprinkling $150 \mathrm{~g}$ of compost in the lines around the rubber trees infected with WRD. The observations were made for 26 weeks after compost application. The observation parameters in this study were: symptoms, rhizomorph colonization on lateral roots, and latex production.

Symptoms of attack can be seen from the rhizomorph of white root fungi that are scattered on the roots of rubber plants. Observations were carried out slowly by digging around the plant roots, starting from the outer soil to the root neck so that it does not damage the roots. The percentage of hyphae/rhizomorph colonization of WRD in lateral roots was calculated by the formula (Triwahyu and Suryaminarsih 2009):

$$
\mathrm{IP}=\frac{\sum(\text { nivi) }}{\mathrm{NV}} \times 100 \%
$$


Where:

ni : number of roots with the ith score

vi : disease score value from i : $0.1,2$ to highest t-score

$\mathrm{N}$ : number of observed lateral roots

$\mathrm{V}$ : highest score

Based on the level of development, WRD attack in the field can be grouped into five (5) scales (Fairuzah et al. 2012): (i) 0: The roots of the plant were free from $R$. Lignosus, (ii) 1: The roots of the plant were covered with $R$. lignosus mycelium but limited to the skin surface, (iii) 2: The mycelium was adhered to the skin and penetrated the wood, (iv) 3: The bark and wood showed rotting, (v) Scale 4: Plants die.

Latex was measured by weighing the latex for each harvest and then the data was pooled.

\section{Data analysis}

The data were analyzed using analysis of variance (ANOVA), with the Duncan's Multiple Range Test (DMRT) comparison among means (Gomez and Gomes 1984).

\section{RESULTS AND DISCUSSION}

\section{Symptoms of infection}

The survey results revealed 3 categories of infection by Rigidoporus lignosus, namely mild, moderate and severe (Figure 1). Symptoms of Rigidoporus lignosus can be seen in the form of rhizomorphs that formed on the roots of rubber plants. The observations indicated that there were differences in the number of $R$. lignosus rhizomorphs in the affected rubber plants. On the severity of the infection, rubber roots were attacked by more rhizomorphs.
In the field, it was observed that the infected roots were colonized by the mycelium causing damage to the roots. White, thick, and thread-like rhizomorphs appeared on infected roots. Rhizomorph can spread to other plants and can be a source of inoculum. In severe symptoms, the base of the stem becomes rot, and the plant easily collapses. Secondary symptoms were seen on the leaves that were pale and yellow, the edges and tips of the leaves were folded inward. Subsequent symptoms result in leaf fall and dead ends of branches. Another symptom was the formation of flowers and fruit earlier. Manurung et al. (2015) reported that white root disease can damage rubber plants. Severe infection results in leaf fall, branch death, bark and root rot causing plant death. The mycelium attack generally occurs around the roots, root neck and base of the stem and causes the roots and stems of rubber plants to blacken, rot and collapse easily. Secondary symptoms are seen in rubber leaves that are dull, wilted, yellow and dry (Amaria and Wardiana 2014).

\section{Disease severity}

The results of the application of compost with the active ingredient of Pseudomonas sp. on rubber plants infected with $R$. lignosus at various levels showed very significant differences. Further tests of the effect of these applications are presented in Table 1. Application of compost enriched with $P$. fluorescens on rubber plants infected with $R$. lignosus suppressed the development of white root disease in rubber. At the end of the observation, it was seen that the treatment of compost enriched with the $P$. fluorescens isolate A and B gave the best results if it was given to light, and moderately infected rubber plants. Application of compost with active mixture of $P$. fluorescens isolates A and $B$ showed better suppression of WRD disease if the rubber plants were infected with mild white root disease.

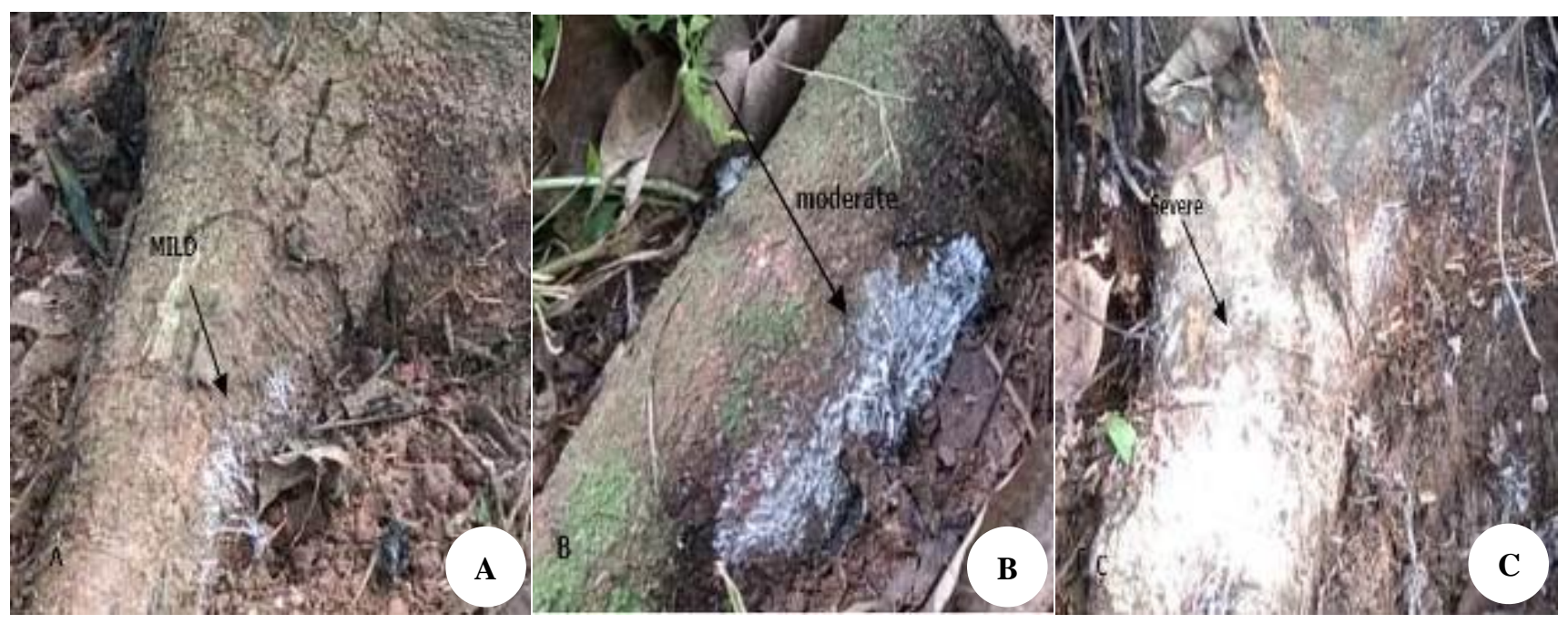

Figure 1. Attack of white root disease caused by R. lignosus on rubber trees in field: mild attack (A), moderate attack (B) and severe $\operatorname{attack}(\mathrm{C})$ 
Table 1. Effect of compost with active ingredients of the antagonistic bacteria Pseudomonas fluorescens on the severity of white root fungal disease in rubber-producing plants.

\begin{tabular}{lcccccc}
\hline \multirow{2}{*}{ Treatments } & \multicolumn{5}{c}{ Average white root disease severity (\%) } \\
\cline { 2 - 7 } & $\begin{array}{c}\text { Before } \\
\text { application }\end{array}$ & $\begin{array}{c}\text { 1 week after } \\
\text { application }\end{array}$ & $\begin{array}{c}\text { 2 week after } \\
\text { application }\end{array}$ & $\begin{array}{c}\text { 3 week after } \\
\text { application }\end{array}$ & $\begin{array}{c}\text { 4 week after } \\
\text { application }\end{array}$ & $\begin{array}{c}\text { 5 week after } \\
\text { application }\end{array}$ \\
\hline BP & $62.56 \mathrm{a}$ & $58.43 \mathrm{a}$ & $55.93 \mathrm{a}$ & $54.68 \mathrm{a}$ & $52.62 \mathrm{a}$ & $51.62 \mathrm{a}$ \\
AP & $61.87 \mathrm{a}$ & $61.87 \mathrm{a}$ & $61.87 \mathrm{a}$ & $57.50 \mathrm{a}$ & $53.06 \mathrm{a}$ & $51.37 \mathrm{a}$ \\
ABP & $59.06 \mathrm{a}$ & $56.19 \mathrm{a}$ & $54.68 \mathrm{a}$ & $54.68 \mathrm{a}$ & $50.50 \mathrm{a}$ & $34.12 \mathrm{a}$ \\
ABS & $40.94 \mathrm{~b}$ & $36.51 \mathrm{~b}$ & $36.51 \mathrm{~b}$ & $35.00 \mathrm{~b}$ & $31.12 \mathrm{~b}$ & $29.31 \mathrm{~b}$ \\
AS & $40.62 \mathrm{~b}$ & $40.62 \mathrm{~b}$ & $40.62 \mathrm{~b}$ & $37.25 \mathrm{~b}$ & $30.93 \mathrm{~b}$ & $29.00 \mathrm{~b}$ \\
BS & $39.40 \mathrm{~b}$ & $37.81 \mathrm{~b}$ & $37.81 \mathrm{~b}$ & $35.00 \mathrm{~b}$ & $32.81 \mathrm{~b}$ & $29.31 \mathrm{~b}$ \\
ABR & $16.50 \mathrm{c}$ & $13.75 \mathrm{c}$ & $13.75 \mathrm{c}$ & $13.75 \mathrm{c}$ & $9.56 \mathrm{c}$ & $7.06 \mathrm{c}$ \\
AR & $16.25 \mathrm{c}$ & $16.25 \mathrm{c}$ & $16.25 \mathrm{c}$ & $14.37 \mathrm{c}$ & $11.50 \mathrm{c}$ & $9.37 \mathrm{c}$ \\
BR & $15.00 \mathrm{c}$ & $13.75 \mathrm{c}$ & $13.75 \mathrm{c}$ & $11.25 \mathrm{c}$ & $10.93 \mathrm{c}$ & $7.06 \mathrm{c}$ \\
\hline
\end{tabular}

Note: Numbers followed by the same letter mean not significantly different at $\mathrm{p} \leq 0.05$ DMRT. A and B (P. fluorescens isolate), R (mild WRD infected rubber plant), S (moderate WRD infected rubber plant), P (severe WRD infected rubber plant).

Table 2. The effect of compost with the active ingredient of Pseudomonas fluorescens antagonist bacteria on latex production of rubber plants.

$\begin{array}{lc}\text { Treatments } & \text { Before application } \\ \text { Control } & 435.00 \mathrm{a} \\ \text { AR } & 379.50 \mathrm{~b} \\ \text { AS } & 367.50 \mathrm{bc} \\ \text { ABR } & 357.00 \mathrm{bcd} \\ \text { BR } & 341.50 \mathrm{cde} \\ \text { BS } & 331.50 \mathrm{cde} \\ \text { ABS } & 326.50 \mathrm{de} \\ \text { BP } & 319.50 \mathrm{de} \\ \text { ABP } & 306.75 \mathrm{e} \\ \text { AP } & 306.75 \mathrm{e}\end{array}$

$\begin{array}{ccc}\text { 1 week after application } & \text { 2 week after application } & \text { 3 week after application } \\ 431.00 \mathrm{a} & 433.50 \mathrm{a} & 438.50 \mathrm{a} \\ 391.50 \mathrm{~b} & 395.75 \mathrm{~b} & 406.00 \mathrm{~b} \\ 385.75 \mathrm{~b} & 368.00 \mathrm{~cd} & 370.00 \mathrm{c} \\ 378.00 \mathrm{bc} & 389.25 \mathrm{bc} & 402.75 \mathrm{~b} \\ 346.25 \mathrm{bcd} & 349.00 \mathrm{de} & 354.25 \mathrm{c} \\ 368.00 \mathrm{bcd} & 358.75 \mathrm{~d} & 360.50 \mathrm{c} \\ 327.50 \mathrm{e} & 329.75 \mathrm{ef} & 352.25 \mathrm{c} \\ 325.50 \mathrm{e} & 314.50 \mathrm{f} & 318.50 \mathrm{~d} \\ 336.00 \mathrm{de} & 307.75 \mathrm{f} & 314.75 \mathrm{~d} \\ 313.00 \mathrm{e} & 318.75 \mathrm{f} & 323.25 \mathrm{~d}\end{array}$

Note: Numbers followed by the same letter mean not significantly different at $\mathrm{p} \leq 0.05$ DMRT. A and B (P. fluorescens isolate), R (mild WRD infected rubber plant), S (moderate WRD infected rubber plant), $\mathrm{P}$ (heavy WRD infected rubber plant)

Application of compost enriched with P. fluorescens isolates $\mathrm{A}$ and $\mathrm{B}$ combined on rubber plants could reduce WRD disease severity by $34.12 \%$ in heavily infected plants, $29.31 \%$ in moderately infected plants and by $57.21 \%$ in mildly infected plants. The application of compost with the active ingredient of $P$. fluorescens was more effective when applied to rubber plants infected with mild WRD disease. Pseudomonas fluorescens can produce siderophores including pyoverdine, salicylic acid and indole acetate which can induce plant resistance to pathogens (Meyer and Leveau 2012; Wahyuni et al. 2015; Damiri et al. 2017). Pseudomonas fluorescens is also reported to be able to inhibit pathogens directly by producing antibiotics such as the antibiotic pyoluteorin 2,4diacetyl phloroglucinol and cyanide acid. Pseudomonas fluorescens can suppress the development of bacterial wilt disease caused by Ralstonia solanacearum in tomato, potatoes, tobacco, banana, and ginger. Pseudomonas fluorescens can also suppress the growth of soil pathogens such as Ralstonia solanacearum, Rhizoctonia solani and Botrytis sp (Nasrun and Burhanuddin 2016 ; Alsohim 2020). In addition, Pseudomonas fluorescens is also known as plant growth-promoting rhizobacteria (PGPR) because it is able to dissolve phosphate and produce plant growth hormones such as IAA which can increase plant growth.
The ability of bacteria to fix nitrogen and dissolve phosphate can improve plant fitness. The ability of bacteria to fix phosphate or nitrogen compounds can increase plant growth and production (Yendyo et al. 2018). P. fluorescens is a rhizobacterium that has the ability to play a major role in the promotion of plant growth, induce systemic resistance in plants, and control plant pathogens (Ganeshan and Kumar 2005).

\section{Latex production in rubber plants}

The results showed that there was a difference in the amount of latex production. Application of compost enriched with $P$. fluorescens was more effective in suppressing WRD when applied to mild to moderately infected rubber plants. The results of the analysis of the application of compost with the active ingredient of $P$. flourescens antagonist bacteria also showed a significant effect on the increase in latex production. The results of tests are presented in Table 2 below.

Application of compost made from active $P$. fluorescens isolates $\mathrm{A}$ and $\mathrm{B}$, either singly or in combination can increase latex production. The highest latex production i.e. 406 gm and 402.74 gm per plant was reported by mild WRD-infected rubber plants treated with compost enriched with $P$. fluorescens isolates $\mathrm{AR}$ and 
ABR, respectively. These two treatments were not different from each other but significantly different from the other treatments and controls. AR, AS, BS, ABS treatments did not differ significantly from each other as well as between $\mathrm{AP}, \mathrm{BP}$ and $\mathrm{ABP}$ treatments, but were significantly different from AR, AS, BS and ABS treatments.

The effect of giving compost with the active ingredient $P$. fluorescens also affects the production of latex. $P$. fluorescens is very suitable as a biological agent because it is found in abundant in soil and plant roots and has the ability to utilize various exudates of various plants as nutrients. Besides that, $P$. fluorescens also has advantages such as the ability to adhere to soil particles and plant rhizoplanes, motility and prototrophy, anti-biotic synthesis and the production of hydrolytic enzymes. Another advantage of $P$. fluorescens is that it has the ability to spur plant growth because it can fix nitrogen, iron chelation, dissolve phosphate and can produce phytohormones (Panpatte et al. 2016). P. fluorescens is a plant pathogenic biological control bacteria, besides that, it is also known as plant growth-promoting rhizobacteria (PGPR) which is capable of producing growth hormones such as Indole Acetic Acid (IAA), which can increase the growth of chili and soybean plants (Susanto at al. 2014; Habazar et al. 2014). According to Nasrun and Burhanuddin (2016), $P$. fluorescens Pf19 produce salicylic acid and phytoalexin which can induce plant resistance and increase the growth of patchouli against bacterial wilted plants. In addition, it was also reported by Khaeruni et al. (2013) that $P$. fluorescens was able to adapt to various conditions and could take advantage of various sources of nutrients so that its population was abundant around the roots of the plant. Therefore, $P$. fluorescens is thought to be able to suppress the growth and development of $R$. lignosus which causes white root fungal disease in rubber plants.

\section{ACKNOWLEDGEMENTS}

The authors would like to thank Dr. Suparman (University of Sriwijaya, Indonesia) whose help and support made the research possible.

\section{REFERENCES}

Alsohim AS. 2020. Influence of Pseudomonas fluorescens mutants produced by transposon mutagenesis on in vitro and in vivo biocontrol and plant growth promotion. Egyptian J Biol Pest Control 30 (19): 1-9. DOI: 10.1186/s41938-020-00220-5

Amaria W, Wardiana E. 2014. The effect of application time and Trichoderma types on white root disease in rubber seedling. J Industr Bever Crops 1 (2): 79-86. DOI: 10.21082/jtidp.v1n2.2014.p79-86

Dalimunthe CI, Tistama R, Wahyuni S, Darwis HS. 2017. Development of serology technique for early detection of white root disease (Rigidoporus Microporus) in rubber plants. Indonesian J Nat Rubber Res 35(2): 129-138. DOI: 10.22302/ppk.jpk.v3512.341

Damiri N, Mulawarman, Umayah A, Agustin SE, Rahmiyah M. 2017. Effect of Pseudomonas spp on infection of Peronospora parasitica (Pers. Fr), the pathogen of downy mildew on Chinese cabbage. IOP Conf Ser Earth Environ Sci 102 (1): 012065 DOI: 10.1088/17551315/102/1/012065.

Fallahzadeh V, Ahmadzadeh M, Marefat A, Ghazanfary K. 2009. Application of rhizobacteria for induction of systemic resistance to bacterial blight of cotton caused by Xanthomonas campestris pv. malavacearum using Fluorescent pseudomonads of rhizosphere. J Plant Protect Res 49 (9):416-420. DOI: 10.2478/v10045-009-0066-5.

Fairuzah Z, Dalimunthe CI, Karyudi, Suryaman S, Widhayati WE. 2014. The effectiveness of several antagonistic fungus (Trichoderma sp.) in Endohevea biofungicide to white root disease (Rigidoporus Microporus) in field scale. Indon J Nat Rubber Res 32 (2): 122-128.

Ganeshan G, Kumar AM. 2005. Pseudomonas fluorescens, a potential bacterial antagonist to control plant diseases. J Plant Interact 1 (3): 123-134. DOI: 10.1080/17429140600907043

Gomez K, Gomez A. 1984. Statistical Procedures For Agricultural Research Second Edition (Vol. 6). An International Rice Research Institute Book John Wiley \& Sons, New York.

Habazar T, Yanti Y, Ritonga C. 2014. Formulation of indigenous rhizobacterial isolates from healthy soybean's root, which ability to promote growth and yield of Soybean. Intl J Adv Sci Eng Inform Technol 4 (5): 377. DOI: 10.18517/ijaseit.4.5.438

Haggag WM, Abo ESM. 2012. Production and optimization of Pseudomonas fluorescens biomass and metabolites for biocontrol of strawberry grey mould. Amer J Plant Sci 3 (7): 836-845. DOI: 10.4236/ajps.2012.37101

Khaeruni A, Wahab A, Taufik M, Sutariati G. 2013. The effectiveness of application time of indigenous rhizobacteria formulation to control Fusarium Wilt and enhance of tomato yield in ultisol soil. J Hort 23 (4): 365-371.

Malmierca MG, Cardoza RE, Alexander NJ, McCormick SP, Hermosa R, Monte E, Gutiérrez S. 2012. Involvement of Trichoderma trichothecenes in the biocontrol activity and induction of plant defense-related genes. Appl Environ Microbiol 78 (14): 4856-4868. DOI: 10.1128/AEM.00385-12

Manjunatha H, Naik MK, Patil MB, Lokesha R, Vasudevan SN. 2012. Isolation and characterization of native fluorescent pseudomonads and antagonistic activity against major plant pathogens. Karnataka J Agric Sci 25 (3): 346-349.

Manurung L, Lubis L, Marheni M, Dalimunthe C. 2015. Testing of various types of active ingredients against white root disease (WRD) (Rigidoporus Microporus (Swartz Fr.) without tillage area (WTA). Journal Online Agroekoteknologi 3 (1): 168-178. DOI: 10.32734/jaet.v3i1.9379.

Meyer KM, Leveau JHJ. 2012. Microbiology of the phyllosphere: A playground for testing ecological concepts. Oecologia 168: 621-629. DOI: 10.1007/s00442-011-2138-2

Nam MG, Wawa NS, Ejolle EE, Nkengafac NJ. 2017. Management of white root rot disease (Fomes) in Hevea Brasiliensis plantations in Cameroon. Amer J Plant Sci 8: 1646-1658. DOI: 10.4236/ajps.2017.87114

Nasrun \& Burhanuddin. 2016. The efficacy evaluation of Pseudomonas fluorescens formulation to control bacterial wilt disease (Ralstonia solanacearum) on patchou. Bull Res Spice Med Crops 27 (1):67-76.

Nasrun \& Nurmansyah. 2015. Potency of rhizobacteria and botanical fungicidea to control white root fungus disease in rubber plant. J Industr Bever Crops 2 (2): 61-68.

Nawangsih AA, Aditya R, Tjahjono B, Negishi H, Suyama K. 2012. Bioefficacy and characterization of plant growth-promoting bacteria to control the bacterial wilt disease of peanut in Indonesia. J Intl Soc Southeast Asian Agric Sci 18 (1): 185-192.

Ogbebor NO, Adekunle AT, Eghafona ON, Ogboghodo AI. 2013. Incidence of Rigidoporus lignosus (Klotzsch) Imaz of Para rubber in Nigeria. Researcher 5 (12):181-184.

Panpatte DG, Jhala YK, Shelat HN, Vyas RV. 2016. Pseudomonas fluorescens: A promising biocontrol agent and pgpr for sustainable agriculture. microbial inoculants in sustainable agricultural. In: Singh $\mathrm{D}$, Singh H, Prabha R (eds). Microbial Inoculants in Sustainable Agricultural Productivity. Springer, New Delhi. DOI: 10.1007/97881-322-2647-5

Soesanto L, Mugiastuti E, Rahayuniati RF. 2010. Antagonistic mechanisms study of Pseudomonas fluorescens P60 on Fusarium oxysporum f.sp. lycopersici in Vivo. Jurnal Hama dan Penyakit Tumbuhan Tropika 10 (2): 108-115.

Soesanto L, Mugiastuti E, Rahayuniati RF. 2014. Liquit formula application of Pseudomonas fluorescens P60 for suppressing viral disease of chilli pepper. Jurnal Fitopatologi Indonesia 9 (6):179-185. DOI: $10.14692 /$ jfi.9.6.179

Tangonan N, Pecho J, Butardo E. 2008. Techo guide on disease of rubber and their management. DA-Bureu of Agricultural research,. University of Southern Mindanao, Kebacan, Cotabato, Philippines. 
Toua D, Messaoud B, Bensid F, Bakour R. 2013. Evaluation of Pseudomonas fluorescens for the biocontrol of fusarium wilt in tomato and flax. Afr J Microbiol Res 7 (48): 5449-5458. DOI: 10.5897/ajmr12.2019

Wahyuni T, Mulawarman, Damiri N. 2015. Population dynamics of rhizobacteria and its potency as a biological control agent to control fusarium disease in the nursery of agarwood (Aquailaria malaccensis Lamrk). Agrivita 37 (37): 276-283. DOI: 10.17503/Agrivita-2015-373-p276-284
Yang C, Hamel C, Vujanovic V, Gan Y. 2011. Fungicide: Modes of action and possible impact on nontarget microorganisms. ISRN Ecol 2011: 130289. DOI: $10.5402 / 2011 / 130289$

Yendyo SGCR, Pandey BR. 2018. Evaluation of Trichoderma spp., Pseudomonas fluorescence and Bacillus subtilis for biological control of Ralstonia wilt of tomato. F1000 Research 6: 2028. DOI: 10.12688/f1000research.12448.1 